\title{
Taxation on Gold Export for Agricultural Developments in Tanzania
}

\author{
Dr. Ranjul Rastogi ${ }^{1} \quad$ Dr.Cairo Paul Mwaitete ${ }^{2}$ \\ 1. Professor, School of Business Galgotias University, Gr.Noida, UP, India \\ 2. Lecturer Institute of Accountancy Arusha, Tanzania
}

\begin{abstract}
This study is about Taxation on Gold Export for agricultural Development in Tanzania. The study reveals that gold export tax plays a significant role in the agricultural productivity of Tanzania once utilized fully for national development as reflected in the findings and suggested on gold export tax push theory identified by the researcher. This is a new theory that suggest government to increase commitment on agricultural development through utilizing gold export revenue. It is unlike today where there is less contribution of gold export to the domestic economy. It is suggested that gold export tax should be introduced since the value of gold is high and stable than the local currency and the USA \$, the government should enjoy the maximum revenue without doubt given the available gold stock. Again gold export is observed to be a lucrative business and benefit more foreign economy through the multinational companies that export it rather than domestic economy that suffer more. This study reveals a significant revenue lost on tax export that once targeted could have improved the performance of the domestic economy through agricultural development. The study recommend that first the government should introduce gold export tax push to improve the agricultural performance and provide farmers with farming tools and technology. Secondly multinational companies must increase transparency and responsibility of paying taxes to the government and reverse the current trend on tax payment before depletion point. Lastly the central bank must make sure that the gold revenue to a large extent must reside in the country to help stimulate the domestic economy. Clear policies to utilize gold export revenue must be in place before gold is depleted.
\end{abstract}

Keywords: Gold Export, Taxation. Agriculture, Gold export tax push, tax revenue

DOI: $10.7176 / \mathrm{JESD} / 10-24-13$

Publication date: December $31^{\text {st }} 2019$

\section{INTRODUCTION}

Taxation is a compulsory contribution levied by the government to its citizen requesting them to pay a certain sum of money during a specified period of time. Taxes can be payable directly or indirectly. For country to develop it require taxes revenues from individuals and firms so as to meet state obligation and public expenditure. The more government raises revenue through taxes the more services should be expected to the people. Therefore government must be innovative when identifying key sources of tax revenue that includes revenue from gold, uranium, gas etc

Tanzania among poor country of the world but rich in natural resources like gold, uranium, gas, diamond, Tanzanite and others. This is also acknowledged by many researchers including Mwaitete (2014), who appreciates that Tanzania has significant stock of natural resources. Tanzania is also acknowledged by having a larger amount of gold stock and is among the gold export country in Africa but remain among the named poor nations of the world. Among the reasons of remaining poor is lower tax base and government revenue from gold export and other key natural resources that could be tapped for development of the country. It is believed that the only way for a nation to develop is the effective utilization of its available resources for the development of the country and Tanzania could benefit the most.

In their paper Rastogi and Mwaitete (2018) revealed that "government must map all gold production for export strategically to benefit more the local economy. Gold export policies should not compromise with the local economy this means to a larger extent money generated from gold export should be ploughed back to the local economy for the better result of Gross Domestic Product (GDP) through increasing agriculture investment and other agricultural inputs for better results of GDP in Tanzania" The authors added that "gold export value should be reflected in the economy with decreased poverty in Tanzania" hence a meaningful economic development. The figure below shows GDP growth rate of Tanzania for the period 1990-2014 
Figure 1.1 Tanzania GDP Growth Rate

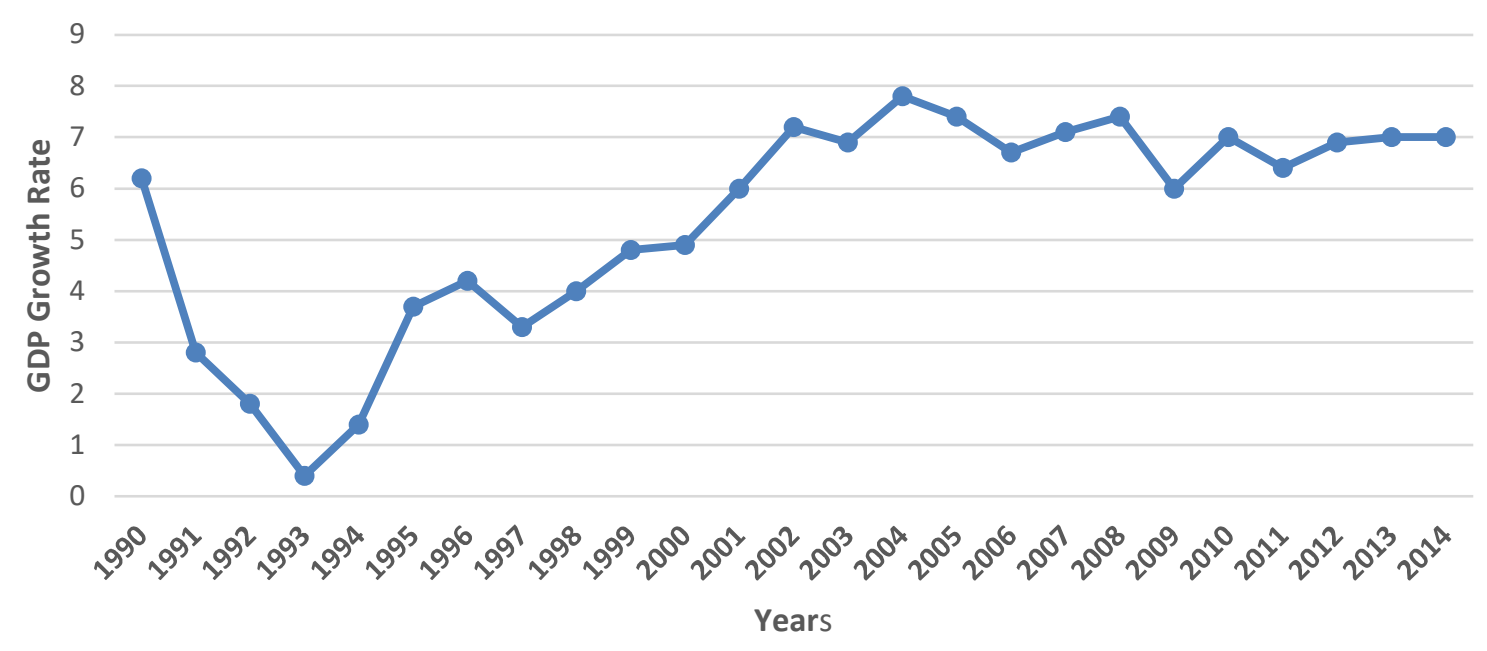

Source: World Bank (2014)

The table above shows that Tanzania economic growth has been growing positively throughout the period 1990-2014 with its lowest level of $0.4 \%$ in 1993 but continued increasing and reached the maximum of $7.8 \%$ in 2004 with slight fall but stable in following years reaching 7\% in 2014.Among the contribution to this growth has been gold export for the named period. Gold has attracted multinational to extract gold in Tanzania given the tax system and other incentives. The little tax on gold export payable on royalties to the government with only $3 \%$ while $97 \%$ is left to multinational.

\subsection{OBJECTIVE}

The main objective of this study is to examine on taxation on gold export for agricultural development in Tanzania 1.2.1 Specific Objectives

- To examine on how gold export can account for agriculture

- To develop new gold export tax push theory that can assist in Tanzania development through agriculture

- To assess past lost gold export tax revenue and the future

\subsection{RESEARCH QUESTIONS}

- How can Gold export account for agriculture and what is gold export tax push theory on agriculture?

- What is the lost opportunity on gold export tax revenue?

- How government can benefit from future gold export tax revenue for Tanzania development

\section{LITERATURE REVIEW}

Tax is considered to be an important factor in development of the country as put forward by (Burges and Stern 1993 ) that the main "purpose of taxation is to raise resources to finance government expenditure. The author suggested that there is a problem in most developing nations in tax design" that could help boost public expenditure and this is the gap in development and reasons for country remaining poor.

Besley and Persson (2013), in their paper they wrote that "states that do not increase tax base are observed to be a weaker states since tax is the catalyst for economic change and therefore government must come up with innovative tax for development" This paper never reveals gold export tax push for development but it is appreciated on acknowledging that tax is the catalyst for development. The authors are appreciated of pointing out "that in the process of development state do not only increase the level of taxes undergo pronounce changes in pattern of taxation with increased emphasize on broader tax base" So increasing tax base on gold export can be one of the area to be focused by the government and this is what the current researcher is attempting to uncover.

Prichard (2010) add the same that "Taxation can be a catalyst of national development and promotion of responsive government in providing government services to its citizen".

Everest (2010) explain that "taxation is considered a state building process" the author is acknowledged through appreciating taxation in development of the country but never reveled tax gap on key natural resources like gold production and export in Tanzania. The author focused on his "seven operating principle of taxation that includes accountability, transparence, political commitment, economic interest, fairness, legitimization of social norms "The author never considered other area like gold export tax.

Ausman, Mutambatsere and Ndiaye (2012), "they focused on royalty taxes and suggested that there is room 
to increase taxes on gold mining since the current rate of taxes were low." The authors never looked at gold export tax push and also they never suggested how countries like Tanzania can benefit from gold export tax. Authors are highly appreciated in pointing out that in "Africa where there is lager number of mining companies and their concession bring about unfair taxes to Africa. The author pointed out that many government offer exemptions to mining companies on corporate taxes, exemptions from royalty's charges and unfair agreement on mining". The author never examined gold export tax push which appear to be significant to Africa if we are to develop as the current researcher is proposing.

Mwaitete (2016), reveals that "gold revenue through export must be ploughed back in a form of reasonable taxes to support the key sectors of the economy like the agriculture sector. Gold export may assist the government with short term finance needs as well as long term financial needs. Gold export can be used to protect the country during the economic crisis" The author applied granger causality test while concluding on his results and never state how much government of Tanzania has lost in gold export Tax. The author again never discovered a theory of gold export tax push that could help change policy and view regarding gold export tax.

Rastogi and Mwaitete (2018) looked at gold export analysis and influence to economic growth where they found that gold export is significant in explaining economic growth of the country. The authors applied multiple regression while explaining this significant and never proposed gold export tax push in their paper. The current researcher is going to explore more in gold export tax push.

\section{DATA AND METHODOLOGY}

Data were collected from the World Bank/IMF and Tanzania ministries. Gold production was available through the Tanzania ministries of energy and the Central bank and it was given in Kilograms and gold price was also obtained from the World Gold Council to examine the annual gold price for each year. The researcher examined the trend of gold export from the year 1990 to 2014 by using excel where the trend function in excel helped to predict the future in graphical form of gold export covering the period 2015 to 2030 given the linearity of the gold export. Data were estimated based on the historical gold export and observation were made on how government can use forecasted data to develop policy that will be used to develop the agriculture hence agricultural development. Gold export tax push theory was developed using graphical approach.

\subsection{FINDINGS AND RESULTS}

\subsection{Gold Export as Foreign Currency Gain to the Country}

Gold export has been a good source of foreign currency to the economy of Tanzania as revealed in the following figure;

\section{Figure 4.1 Gold Export}

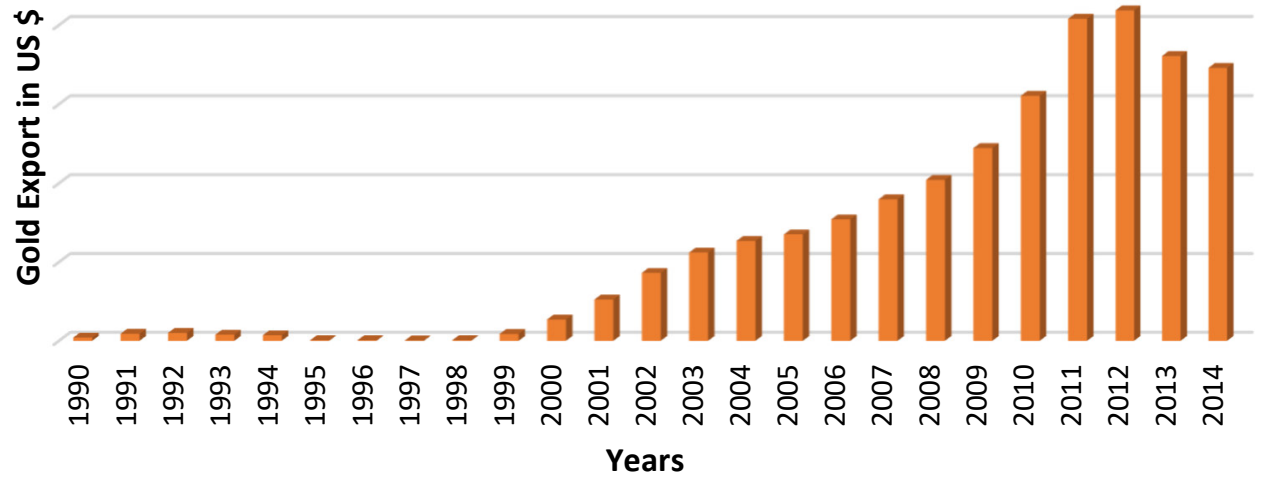

Gold export has generally been positively growing as reflected in the above figure adding to more foreign currency to the country while creating more local jobs. Despite of exporting the raw gold the contribution is important to the economy of the country mainly the GDP. During the reported period in 1990 gold export brought about US \$20,257,938 and has been positively growing with its highest level of US \$2,093,294,465 in the year 2012 then slightly fell in the years 2013 to 2014 but not significant fall reaching the level of US $\$ 1,729,807,293$ and US $\$ 1,804,633,295$ respectively. The gain in the form job creation and taxes to the government even if it is a little amount of taxes where the government gets $3 \%$ of gold export and the rest goes to the gold producers and their shareholders and operating cost which is $97 \%$.

It is evidenced that when government focus on the gold export can realize more source of foreign currency to 
the government and help support other sectors of the economy like agriculture sector when good policies are developed from the gold export. Gold price is stable in the world market and Tanzania must benefit more before gold is depleted.

Figure 4.2 World Gold Price in US \$ From 1980-2015

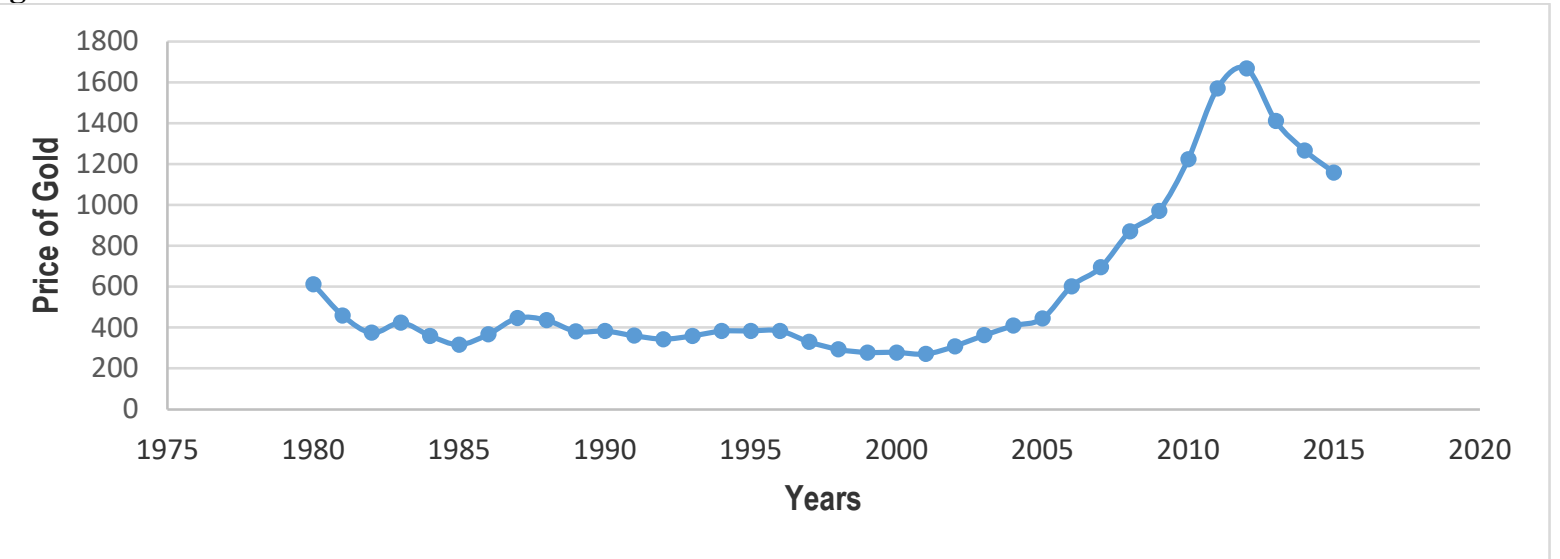

Source: Statista (2016).

The above figure demonstrates the price of Gold per ounce of US \$ produced from 1980 to 2014 Statista (2016). The figure shows that the price of Gold has been positively increasing despite its fluctuations but stable from its initial of US \$ 613 in 1980 and slightly fell in the following years reaching us \$ 385.51 per ounce in 1990 to its maximum level of US \$ 1668.98 in 2012 again slightly fell but not significant fall to US \$ 1266.4 in 2014 . Gold price is stable and promising given the study period. The trend in Gold price is suggested to be strong throughout years and given the scenario where Tanzania has Gold stock can benefit more to improve welfare of the people if mapped strategically with right policies that are pro-poor especially through utilizing gold revenue to improve the agriculture sector also this acknowledged by (Mwaitete 2014) and (Mwaitete and Rastogi 2016). In general Tanzania has benefited less from gold price and trend.

Figure 4.3 Tanzania Gold Production (KG) from 1980-2015

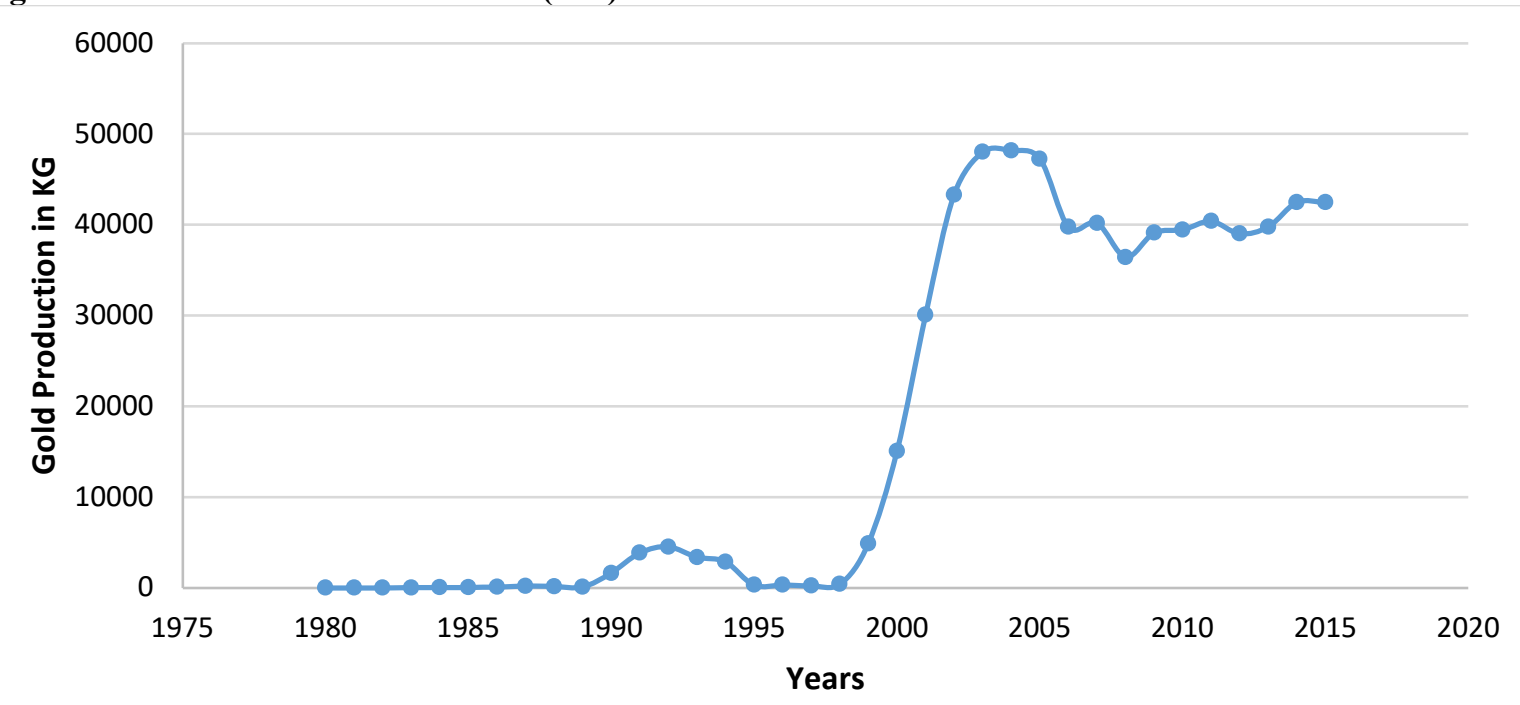

Source: Bank of Tanzania (2015)

The figure above depict the production trend in Tanzania that if well mapped could have been used to rescue the agriculture sector. The trend suggest that there has been sharp increase of production during the period late 1990's with lower production in 1980's. The peak reached in $48176 \mathrm{Kg}$ in 2004 alone and slightly fell down to 42486 in 2014.Generally gold production has been growing for several years now due to poor police in Tanzania that favor the gold production without any proper consideration on domestic economy and VAT on export that could be used to improve agriculture sector.

\subsection{How Can Gold Export Account for Agriculture?}

As pointed out in the literature that "Tanzania is among the 15 world gold producing countries and gold export dominated total export to a large extent as revealed by the World Gold Council(2016) that gold from Tanzania 
represented 36\% of total export in the year 2012 alone." Also Gold stock is money by itself Tanzania must change policies to reflect the valuable resource can be ploughed back to other sector of the economy where majority of the people dwell and this is the agriculture sector. Given the gold export in Tanzania as shown here below and analyzed somewhere in this report please recall the gold export from 1990 to 2014 alone

Figure 4.4 Tanzania Gold Export 1990 to 2014

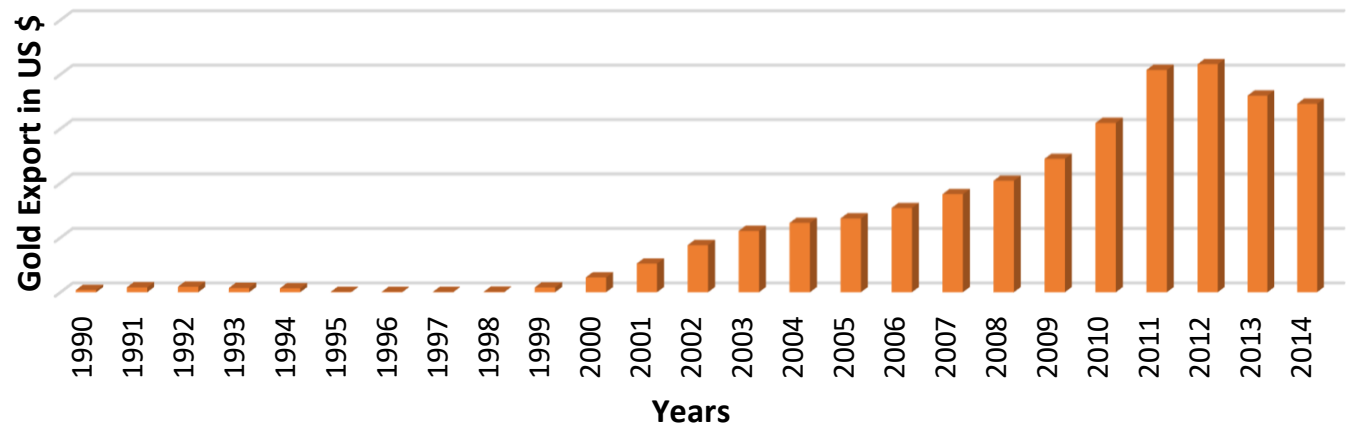

The contribution of gold export has not be given priority in Tanzania, the period 1990-2014 the government has been charging 3\% of gold royalty and $97 \%$ of gold export value goes abroad to where most of the key gold producer reside who actually underestimate even the level of the export values and sales.

\subsubsection{Gold Export Tax Push}

Gold export tax should be introduced since the value of gold is high and stable value than the local currency and the USA \$, the government should enjoy the maximum revenue without doubt. At par with other commodities tax in Tanzania, the government should introduce the tax on gold export. Gold companies will be willing to pay taxes given the stability of Gold to the world market and to the assumption that currently gold producers and sellers do not pay Value Added Tax so introducing the export tax will be the best strategy for Tanzania to develop. Revenue received from gold export tax should be directly to mechanize agriculture in the country: 4.3.13 Assumptions on Gold Export Tax Push and Agriculture Productivity

- Value of Gold is stable throughout the period $\mathrm{t}$

- Gold Producer will be willing to pay since they currently don't pay VAT on gold export

- When Initial Tax is introduced

- Additional taxes to gold exporter of raw gold and bars

- Holding Gold stock is more valuable and therefore certain control through taxes is needed

- Gold is depletable resource

- Get revenue tax shall be used for the intended purpose agriculture mechanization

- Gold is durable commodity

Figure 4.5 Gold Export Tax Push on Agriculture Productivity

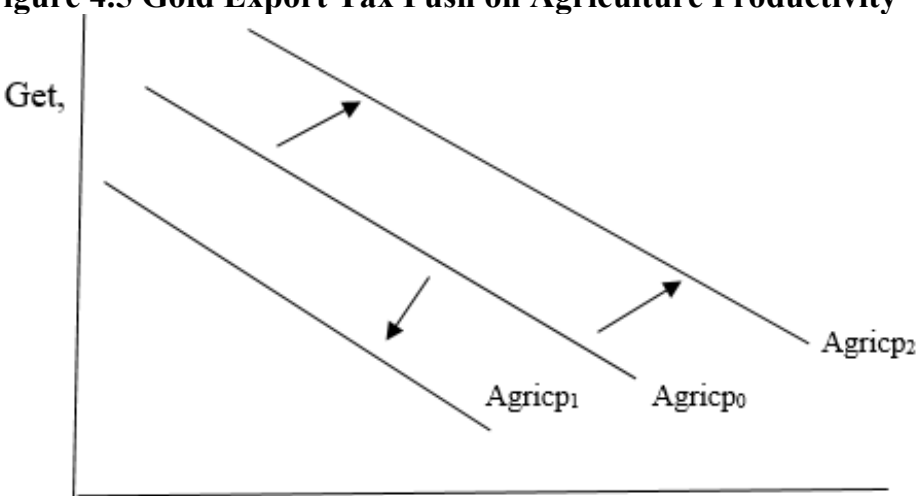

Agriculture Output (Q)

Where :

Get $=$ Gold export tax at time $\mathrm{t}$

Agricp $_{0}=$ initial Agriculture Productivity before

Agricp $_{2}=$ Agriculture Productivity after Get Push

Agricp $_{1}=$ Agriculture Productivity when Get is reduced

The above figure shows that the government want to improve agriculture productivity and they have no 
alternative but to use its own available resources like gold resources that can reverse the current falling trend on the agricultural productivity in the country. At its initial, agricultural productivity before Gold export tax push is introduced at time $t$, the agriculture was - Agricp $_{0}$, after tax consideration it push up the agricultural output to the right - Agricp 2 . Agriculture Productivity has improved due to Get Push on agricultural production and therefore poverty alleviation among farmers. When Gold export tax at time $t$ is reduced then agricultural productivity will move to the left - Agricp 1 and poverty prevail among farmers.

\section{Gold export (Get) -Target}

When agriculture productivity is increased to $80 \%$ farmers in Tanzania then livelihood shall be improved among the people and income shall be increased among the people, malnutrition shall be reduced significantly and income poverty in the society shall be generally reduced as well and this is the target of Get in agricultural development and poverty alleviation.

This is the multiplier effect of Get in alleviating poverty in Tanzania at time $t_{0}$

Because gold stock in Tanzania is given freely by nature and is abundant and more is to be discovered, Gold stock is also considered to be a depletable resource at time $t_{0}$. Get tend to behave as follows in the long run perspectives;

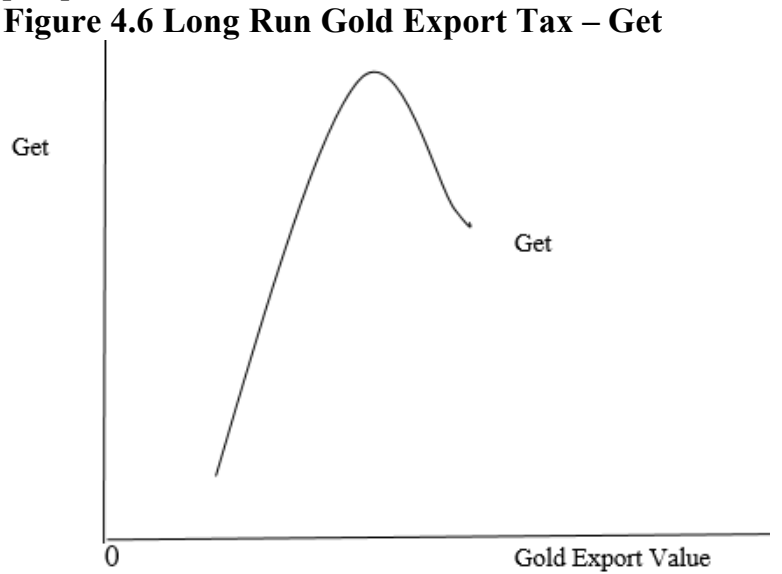

At the initial Gold Export Tax -Get will be increasing at increasing rate of Get and more revenue generated to government to finance agriculture and reaches its maximum value of Get, gold shall start diminishing because it is depletable resource and Gold Export Tax will start falling because there less gold in the long run. Therefore a great care should be introduced today through (Get) taxes needed to control depletion rate and making gold as more valuable while investing more Get revenue in agricultural development hence alleviating poverty.

\subsection{Lost Gold Export Tax Revenue Opportunity for Development}

Tanzania require taxes in order to improve public expenditure and bring about development to citizen and the only way to achieve this is through taxes. Tanzania charges taxes to any other product produced in the country and any product sold or bought is subjected to gold Value Added Tax (VAT) but this is not the case of gold export that enjoy free zone from VAT payment. The government is losing a lot of revenue from this lucrative business which mainly dominated by multinational.

Figure 4.7 Tanzania lost Opportunity of Gold Export Tax Revenue and the Push to Agriculture

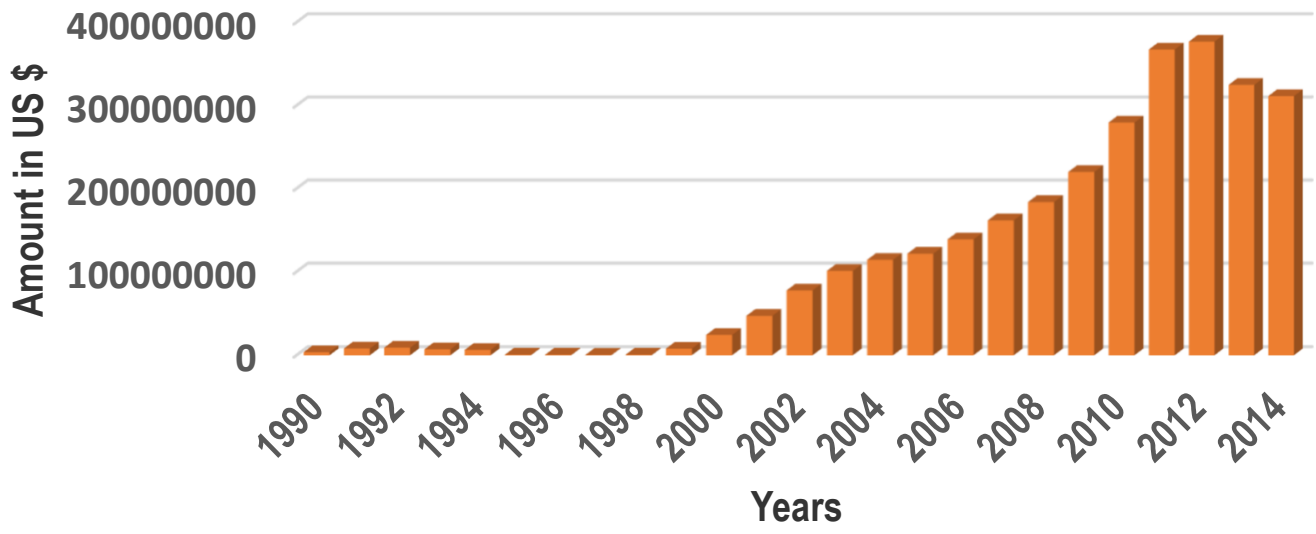

The above figure and the table bellows demonstrate how Tanzania has failed to capture gold export for 
agricultural development in the country starting from the year 1990 to 2014.The amount is in US \$ and the exchange rate today is US \$ 1 = Tanzania shillings 2,270 this means that Tanzania has lost a total value of

US \$ 2894926291 from 1990 to 2014 or this is equivalent to Tanzania shillings 6,571,482,680,570 lost opportunity to Tanzania from 1990-2014 that could have been captured to push development in the country especially in agriculture. The amount could have transformed agriculture and make sure that every village has at least one tractor and other agricultural inputs to support farm agricultural development hence increasing the output and alleviating poverty.

The lost opportunity is also revealed in Tanzania agriculture food security and investment plan(TAFSIP) they had a clear vision to uplift the agriculture sector but it fell short of financing during the named period with a total financing gap amounting to US \$2877Million required to improve the sector. In 2012 alone only US \$269 million was required, 2013 was US \$ 524 million, 2014 was US \$ 596 million was required. Gold export could have accounted for all these. Gold export could have accounted for TAFSIP plan for agriculture and beyond.

Reference is also made from the government on the annual national budget for Tanzania shillings with public expenditure in fiscal years 2008-9 to 2011-12. It shows that the budget for the year 2008-9 was 6522 billion but only $3.95 \%$ of agriculture expenditure was allocated by the government. In 2009-10 the national budget was 9509 billion but only $3.58 \%$ of agriculture expenditure was allocated. Furthermore in 2010-11 national budget with public expenditure of 11609 billion only $3.04 \%$ of agriculture expenditure was allocated for agriculture while in 2011-12 the total national budget was 13526 billion but 6.8\% . The government fails to meet even some very basics in agriculture financing requirement of annual $10 \%$ required to be allocated for agriculture from total national budget. This demonstrate that something has to be done to rescue the situation and this is through examining the role of gold export.

Furthermore it is discovered from Tanzania that they never charge value added Tax on gold export. The value added tax is charged to other commodities that is why the researcher is proposing the government to become strong and introduce export tax to all gold export and related commodities that tax could then be used to finance agriculture directly in the country and improve livelihood among the majority of the people who account $80 \%$ of the population.

Table 4.1 Tanzania lost Opportunity of Gold Export Tax Push

\begin{tabular}{|r|r|r|}
\hline & Annual Gold Export (in US\$ ) & Gold export Tax at 18\% (Assumed) \\
\hline 1990 & 20257937.8 & 3646428.804 \\
\hline 1991 & 44708902.71 & 8047602.488 \\
\hline 1992 & 50018503.83 & 9003330.689 \\
\hline 1993 & 38979460.54 & 7016302.896 \\
\hline 1994 & 35320761.6 & 6357737.088 \\
\hline 1995 & 3952340.96 & 711421.3728 \\
\hline 1996 & 3933773.049 & 708079.1488 \\
\hline 1997 & 2468713.624 & 444368.4523 \\
\hline 1998 & 4039341.432 & 727081.4578 \\
\hline 1999 & 43843700.88 & 7891866.158 \\
\hline 2000 & 135139200.7 & 24325056.12 \\
\hline 2001 & 262184906.4 & 47193283.15 \\
\hline 2002 & 431372740.7 & 77647093.33 \\
\hline 2003 & 560978304 & 100976094.7 \\
\hline 2004 & 634598263.6 & 114227687.5 \\
\hline 2005 & 675884942.6 & 121659289.7 \\
\hline 2006 & 771199250.3 & 138815865 \\
\hline 2007 & 898586400.2 & 161745552 \\
\hline 2008 & 1021314481 & 183836606.7 \\
\hline 2009 & 1222713546 & 220088438.4 \\
\hline 2010 & 1553014091 & 279542536.4 \\
\hline 2011 & 2040679224 & 367322260.2 \\
\hline 2012 & 2093294465 & 376793003.8 \\
\hline 2013 & 1804633295 & 324833993.1 \\
\hline 2014 & 1729807293 & 311365312.8 \\
\hline
\end{tabular}

\section{Why 18\% tax is Assumed Appropriate for Gold Export Tax Push in agriculture?}

All other goods and services produced locally they are compelled to pay value added tax of $18 \%$ and therefore it makes sense for the government to introduce this at the initial stage of Gold Export Tax Push for agriculture. Gold and other mines they have been exempted from value added tax for so many years and therefore lost opportunity for development to the government. 


\subsection{Government Benefiting From Future Gold Export Tax Revenue for Tanzania Development}

Researcher projected data based on the historical time series for the actual gold export revenues in US \$ and were fixed in excel then projected. Data from 1990 to 2014 were the actual data and researcher used these data to project the trend from 2015-2030 to examine how much government should expect to collect from gold export tax given the assumed tax rate of $18 \%$ on gold export tax. The following figure shows the trend in US\$

Figure 4.8 Tanzania Actual Gold Export 1990-2014 and Future Trend Gold Export 2015-2030

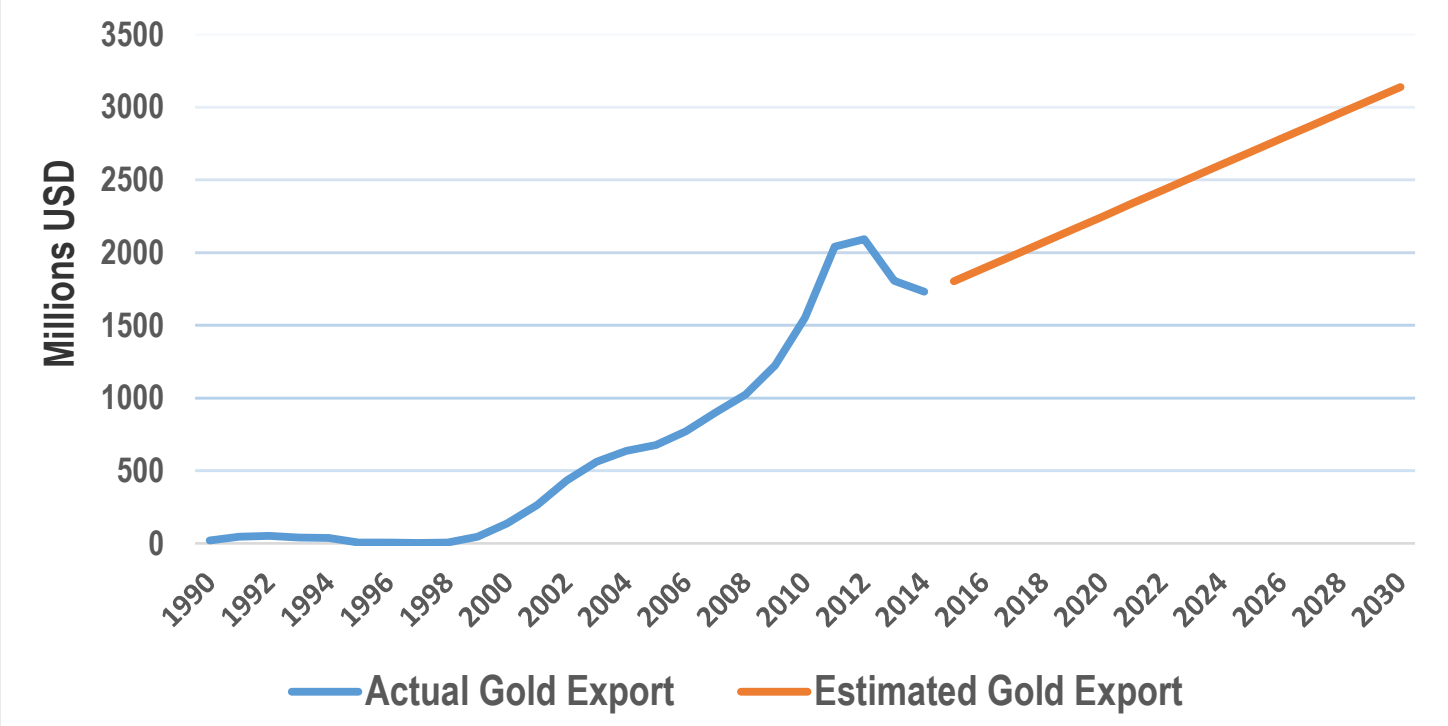

The above figure shows Tanzania Actual Gold Export 1990-2014 and Future Trend Gold Export 2015-2030.It reveals that gold export is positively increasing based on this estimate from the year 2015 to 2030.Initally the amount in 2018 is expected to be US $\$ 2,069,065,147$ with a targeted gold export tax at $18 \%$ (Assumed) of US $\$ 37,2431,726.4$. This amount is significant in setting farm investment. It is projected that these revenue will keep on increasing and reaching a total revenue US $\$ 39,520,909,221$ for all projected years. This positive increase of gold export should be realized in agriculture productivity through export tax.

Figure 4.9 Projected Gold Export Tax in US \$ From 2015 to 2030

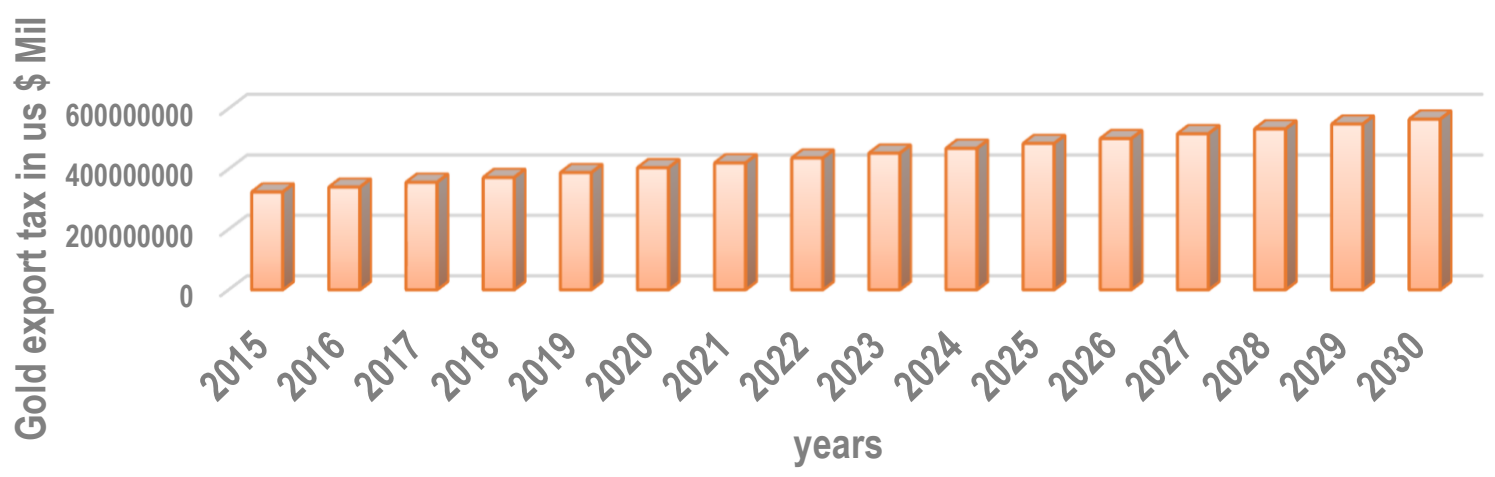

The figure above demonstrate the Gold export tax revenue trend at $18 \%$ in each year from 2015 to 2030 . The figure reveals that the projected amount can be target to account for agriculture productivity and growth in Tanzania. It also reveals a positive growth trend on tax revenue if mapped properly by the government. In 2015 alone tax revenue was projected to be US\$ 324,312,724.9 the amount keep on increasing US \$ 404,511,060.8 in the year 2020 and continue rising and reach the peak in 2030 with estimated tax revenue of US $\$ 564,907,732.5$.This annual amount when targeted could make revolution in agriculture in Tanzania while improving livelihood of the people, income and poverty alleviation in the country. The targeted amount can be used to improve farm technology, machines setting up farm infrastructure and agricultural inputs given the arable land. The country will be self-sufficient with food and reduced hunger among citizens. Therefore the government should decide when to implement the policy. 


\section{Conclusion and Recommendations \\ 5.1 Conclusion}

Gold export tax plays a significant role in the agriculture productivity of Tanzania once utilized fully for national development as revealed in the findings and suggested on gold export tax push theory. Gold export tax should be introduced since the value of gold is high and stable value than the local currency and the USA \$, the government should enjoy the maximum revenue without doubt given the available gold stock. At par with other commodities tax in Tanzania, the government should introduce the tax on gold export. Gold companies will be willing to pay taxes given the stability of Gold to the world market and to the assumption that currently gold producers and sellers do not pay Value Added Tax so introducing the export tax will be the best strategy for Tanzania to develop. Revenue received from gold export tax should be directly to mechanize agriculture in the country and support farmers with agricultural input. The study conclude that gold export tax push should be used to account for agricultural development in Tanzania in order to develop. If gold is not used wisely one day the stock of gold will be finished and country will be left with holes, for this case strategic use of gold export should be enhanced

\subsection{Recommendations}

\section{Gold Export Tax Revenue}

Gold export tax should be introduced since the value of gold is high with stable price than the local currency and the USA \$, and it is regarded as a lucrative business with high profit the government should enjoy the maximum revenue and gold producers will be willing to pay since currently there is no Value Added Tax on gold export revenue.

\section{Gold Export and Agriculture Productivity}

Gold export tax revenue in exchange should be used to improve the agriculture sector through

$\checkmark$ Providing farmers with modern farming tools, machines and tractors in every village where farmers reside

$\checkmark$ Provide enough subsidies to farmers requiring support from the government including fertilizers

$\checkmark$ Set up farm infrastructure including road and industries for farmer's value chain addition.

$\checkmark \quad$ Set up water harvest strategy, water reserve and irrigation and farming should be done the whole year round

\section{The Multinationals companies exporting gold}

The involvement of multinational companies in gold exploitation and export who pays $3 \%$ to the government and take out $97 \%$ must be limited and those involved in gold export should not be given tax exemptions. The current Gold companies and their tax system must be reversed and make sure that large proportions of gold export income remain domestically to improve GDP in Tanzania through improving the agriculture sector.

\section{The Central Bank of Tanzania}

The central bank must make sure that the gold revenue to a large extent must reside in the country to help stimulate the domestic economy. Gold export value can be used to supply the nation with technological needs especially technology to support agriculture. Gold export can be used to protect the country during the economic crisis and stabilizing the economy through stable currency unlike today where there is no link to gold export and the level of economic growth. Gold is money by itself and therefore clear strategy is required on how to use gold for development

\section{REFERENCES}

Ausman G, Mutambatsere E and Ndiaye G (2012), Royalty Rates in Africa Mining Revisited: Evidence From Gold Mining, African economic Brief, Africa Development Institute, AFDB, Volume 3 issue 6.

Besley, T., \& Persson, T. (2013). Taxation and development. In Handbook of public economics (Vol. 5, pp. 51110). Elsevier.

Burgess, R. and Stern, N. (1993). Taxation and development. Journal of economic literature, 31(2), pp.762-830.

Everest Phillips, M. (2010). State-Building Taxation for Developing Countries: Principles for Reform. Development Policy Review, 28(1), 75-96.

Mwaitete C.P, (2014), Critical Analysis of Poverty alleviation Strategies and the Use of Natural Resources: A case of Tanzania, ZENITH International Journal of Business Economics \& Management Research, ZIJBEMR, Vol.4 (9), SEPTEMBER (2014), ISSN 2249- 8826

Mwaitete C.P (2016), Gold Export and Economic Growth: Granger Causality and Co-integration a Case of Tanzania, Imperial Journal of Interdisciplinary Research (IJIR) Vol-2, Issue-12, 2016 ISSN: 2454-1362

Prichard, $W$. (2010). Taxation and state building: Towards a governance focused tax reform agenda. IDS Working Papers, 2010(341), 01-55.

Rastogi, R., \& Mwaitete, C. P. Gold Export Analysis and Influence to the Economy of Tanzania: Multiple Regression Analysis. Journal of Economics and Sustainable Development, ISSN 2222-2855 (Online) Vol.9, No.18, 2018

Statista (2016), Annual average gold price from 1900 to 2015 , 55 Broad Street 30th floor, New York, NY 10004, 
United States, available online at http://www.statista.com/statistics/268027/chan ge-in-gold-price-since1990/

World Gold Council (2016), World Official Gold Holding, Available online at http://www.gold.org/research/latest-world-official-gold-reserves

World Bank (2014), Tanzania Economic Overview: Performance and Outlook, 1818 H Street, NW Washington, DC 20433 USA also available online at http://www.worldbank.org/en/about 